\title{
Reflections on Museum Week 2018 and Restitution
}

\author{
Lucia Patrizio Gunning* \\ History Department, University College London, UK
}

Submission: July 26, 2018; Published: August 02, 2018

*Corresponding author: Lucia Patrizio Gunning, History Department, University College London, Gower Street, UK, Tel: +44 (0) 777 916 4564 ; Email: l.gunning@ucl.ac.uk

Keywords: Museum; Momentum; Identity; Artefacts; Urgent task; Cultural; Self-scrutiny; Mobilization; Felwine Sarr; Bénédicte Savoy; Macron; Cultural Heritage

\section{Opinion}

Discussions on restitution have been acquiring momentum. Museum Week in 2018 has been marked in the press by a series of articles which support this direction. It started with an email from an Indian colleague who was at the ARCA conference last year where I was talking about the history of collecting of European museums and the gathering of antiquities during the late $18^{\text {th }}$ and early $19^{\text {th }}$ century. This is an argument about which I have been very passionate and that has been at the core of my research interests, teaching and public engagement, since my postgraduate days.

On the Queen's birthday, Anuraag Saxena had written a provocative and passionate article Your Majesty: Thou shalt not steal on the need to return Indian artefacts to India, calling for a 'reverse [of] the colonial-era plunder, especially symbols of our culture - our heritage'. With the India Pride Project, Anuraag is an active proponent of the repatriation of looted Indian artefacts, and his argument gained strength and momentum with the declaration by the French President, Emmanuel Macron, of the intention to return African artefacts. This was not just an announcement in the way politicians do them, because Macron has already given the task to Felwine Sarr and Bénédicte Savoy, and a deadline, to see the job to completion.

Macron has stated that "African heritage cannot be a prisoner of European museums." Most importantly, he made his announcement in a joint appearance with the president of Benin Patrice Talon. Benin has been campaigning for a return of its cultural heritage, not only from France, for several years. In fact, it was the British who took their most treasured possessions and put them on the market in retaliation for an uprising in 1897.

On the 6 March 2016 the Guardian published an article giving voice to a student protest in Cambridge which demanded that a Benin cockerel held at the entrance of Jesus College should be returned to its rightful owners.
The British Museum celebrated museum week with the Europe and the World, a Symphony of Cultures project promoted by the new director Hartwig Fischer. I took myself to hear the beautiful Ottoman and Versailles court music in room 6 on the Sunday afternoon. In the presentation page of the website, Fisher had declared that: "The world collections of the British Museum provide extraordinary opportunities for musical performance. Here the material inheritance of the world's cultures is stored and deciphered, and we are invited to interpret the ways that regions and peoples assert their identities - an endless and urgent task."

Fisher shared in this thought the ideas of Macron, stating himself that we need to recognise that culture, and artefacts, pair with "identity" and that there is an "urgent task" that needs attention. Yet the approach is indeed different, if on one side the French government has officially undertaken the task to reunite colonial countries with their artefacts, recognizing that it is time to reverse actions that have been done in the past, in Britain this call has remained unanswered. Here Fisher has put an emphasis on how cultures can mutually play and strengthen themselves reciprocally. Yet I find this approach hypocritical and another way to dominate them culturally yet again.

Although fascinated by the beautiful music, I could not quite make the connection myself of how music played in the British Museum in London would help middle eastern people to reassert their identity at home. During the same week, the Guardian published the news that the V\&A had hinted to the return of Ethiopian artefacts on a long-term loan basis. After the French news, this move was perhaps inevitable, yet a step in the right direction, and a demonstration that Tristram Hunt had sensibly bent to the call of the Benin ambassador on the eve of the exhibition opening. Whether this was a conscious decision, or the surprised response to a highly sensitive issue after the outspoken speech by the ambassador, this represented 
a positive and unprecedented step forward in the current debate on restitution in England, especially when considering that in a Guardian interview Fisher had said only two weeks before that "the [British]museum will bring a much greater sense of selfscrutiny to its displays", hinting that restitution issues are not on the agenda. It is from the same article that I learn that Fisher has married the Cuno idea of "a museum of the world for the world", a way to say that the artefacts are staying put.

Therefore, I was pleasantly surprised to read the next day about the fuss my former student Alice Procter was causing with her museum tours designed after she attended my course Collecting for the Nation at UCL which explains to students how the history of collecting for European museums is fundamental for the understanding of the wider issue of ownership, repatriation, and current legislation and the development of the art market. Alice elaborated the concepts studied by designing provocative museum tours that show the history of the pieces and present the institutions in a different light. This caused an outcry in some papers, enough to let the Guardian give her a voice to explain her reasoning behind the tours: 'I make "Display It Like You Stole It" badges for people to wear on the tours. It's a slogan designed to push museums and visitors to rethink the politics of presentation in galleries. On most text panels there's little or no mention of how objects came to be there. Euphemistic language of "acquisition" obscures the truth. I don't believe most visitors to the British Museum's Benin and South Pacific collections, for example, or the V\&A's Indian collections, come away understanding that these are largely the spoils of war.'

Alice concluded her article by saying that her tours will continue until 'museums engage fully with their imperial legacies without needing to be prompted. I don't know when that will happen, but it must.'

Museums have disassociated themselves from her tours, yet, these have the scope to provoke people to think that the narrative presented by museums themselves leaves out the knowledge of how they got their collections, a history that is becoming ever more fundamental if museums want to establish a position of transparency going forward.

Notwithstanding the amazing work that museums, and especially the British Museum Middle East and Egyptian Departments are doing to reconnect and empower people in countries at war, coming up with a position of transparency on the history of the pieces they hold would create a novel and ethical position. Facing the past would allow to discuss the future.

I have written in a previous article that "Approaches that were possible and legal through the eighteenth and most of the nineteenth centuries are now both unthinkable and illegal", this means that if the acquisition of antiquities was not illegal yet poses several moral issues in modern times.
On $15^{\text {th }}$ of April Marc Masurovsky, co-founder of the Holocaust Art Restitution Project, had published his presentation for the annual conference of the Lawyers' Committee for Cultural Heritage Preservation (LCCHP), which took place in Washington, DC a couple of days earlier. There, he had remarked that he has "always viewed restitution, as part of an overall healing process, a salve on a trans-generational traumatic scar".

But restitution is a complex issue, all sorts of complications and ethics come into play, as well as the politics and historical imbalances that have created those positions of privilege that have allowed the removals. An exact understanding of the circumstances that have caused the artefacts to change location is therefore essential to establish a position of competence.

Another passage of his talk is worth quoting as it coincides with my thoughts again: "From an ethical and moral standpoint, the repatriation of looted objects to autocratic and dictatorial nations can be viewed as problematic. But what is the alternative? Prevent those objects from returning to their source? Under what pretense? That we are morally and culturally superior? If we follow those arguments, we are no better than 19th century colonial adventurers who viewed the "others" as inferiors and whose assets should best be handled by the Western world. We cannot allow ourselves to think that we are morally superior to anyone."

Although he was talking about contemporary looted objects and holocaust restitution, the concept applies to some historical acquisitions. So many times, the argument that Western European museums provide a safe haven for artefacts that would have otherwise been damaged, destroyed or forgotten, has been used to discard claims of restitution. But who says that one population has righter than another to hold an object?

"Art objects are an integral part of our individual and collective memory of the past and the present. They are an extension of who and what we are. For those reasons, it is as important to transcribe faithfully and truthfully the story of these objects as it is to recover them. Every cultural object, regardless of origin, deserves a thoroughly fleshed out provenance before it is displayed or traded. Ignorance, arrogance and greed are the enemy. One way to forestall future acts of State-sanctioned plunder is to ensure that the history of these objects and their owners is written, published, disseminated and taught to as wide a public as possible."

I have been doing exactly that. By teaching my history of collecting course and researching the way antiquities have arrived to museums, I have been trying to sensibilise the public to the necessity to come to terms with this history. In particular, I believe that the best way forward for encyclopaedic museums is for them to open up their archives to the public, providing absolute transparency about the history of their collections. This clarity of position will allow a constructive conversation about their future. 
Masurovsky therefore, concludes where I started, with the conviction that the history of collecting, the study of the archival documentation of museums and public records that allow us to recover the full undisclosed story of those acquisitions, is the essential passage to open a future of collaboration and peaceful, unresentful exploration of the future. Teaching that history, is just as essential. So, the week finished decisively in a positive note, with the announcement that the German government is pouring money into doing exactly that.
I wonder how long it will take for the British government to start focusing its attention on these issues. The foundation of the Schools of Archaeology in Athens was financed first by the French in 1846 with Germany following suit in 1876. The British School of Archaeology was eventually established ten years later at the invitation of the Greek government and the donation of land to build on.

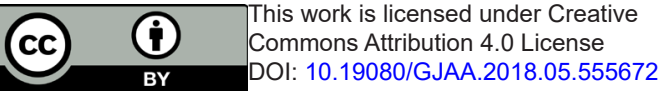

\section{Your next submission with Juniper Publishers will reach you the below assets}

- Quality Editorial service

- Swift Peer Review

- Reprints availability

- E-prints Service

- Manuscript Podcast for convenient understanding

- Global attainment for your research

- Manuscript accessibility in different formats

( Pdf, E-pub, Full Text, Audio)

- Unceasing customer service

Track the below URL for one-step submission https://juniperpublishers.com/online-submission.php 